\title{
The Implementation of One-Stop Integrated Service Policy in Klungkung Regency
}

\author{
Ni Putu Tirka Widanti, Anak Agung Gde Raka, I Made Surya Atmadja \\ Master of Public Administration Science, Ngurah Rai University, Bali (email: tirka widanti@gmail.com)
}

\begin{abstract}
The government of Klungkung Regency is one of the Regencies in Bali that carried out reforms in order to simplify the licensing process by holding one-stop integrated service. The purpose of this study is to determine the implementation of the policy and the inhibiting factors of the one-stop integrated service. Van Horn and Van Meter Theory were used in this research. The research was conducted at the Department of Investment and One-Stop Integrated Services in Klungkung Regency by using a qualitative research method. The result is that the implementation of the policy shows a tendency for increasingly improved attitudes. The inhibiting factor of the implementation of the policy is the different perception between the Department of Investment and the technical team related to the administrative services and the unavailability of a public service mall to facilitate the licensing and non-licensing process. In terms of human resources, the inhibiting factors are related to professionalism, competence, empathy, and ethics. The next problem is the minimal service quality that complicates the process.
\end{abstract}

\section{Keywords:}

Implementation; policy; one-stop integrated service

\section{Introduction}

Public service is a community need. Faced with the growing demand for the public service, the local government is now having difficulty in providing adequate and balanced supply due to low efficiency and insufficient co-ordination. Therefore, the most urgent thing is to take effective measures to promote the local ability to provide public service. Yang, Y., 2016, 1). The government is required to provide community-oriented services and needs. Therefore, a reform through the new organizational models to provide public services based on the customer's point of view, both the general public and the business community (Umar, A., Madani, M., Farida, U., Yusriadi, Y., Tamsa, H., Yahya, M., ... \& Sakkir, G., 2019, 1). In fulfilling the interests of the community, the government of Klungkung regency organizes the one-stop integrated services. 
The Department of Investment and One-Stop Integrated Services (Dinas Penanaman Modal dan Pelayanan Terpadu Satu Pintu) of Klungkung regency has a licensing and nonlicensing mechanism or service. The operational standard of the procedure for the licensing service is known that the permit application is in one place. However, the fact is that the technical team is still in its parent agency so that the licensing process will take time. The form of services provided by the Department of Investment and Integrated Services for the past two years can be seen in the following table:

Table 1.1

Targets and Realization of Licensing Performance Indicators

\begin{tabular}{|c|c|c|c|c|c|}
\hline \multirow{2}{*}{ Purpose } & Performance & \multicolumn{2}{|c|}{ Target } & \multicolumn{2}{c|}{ Realization } \\
\cline { 3 - 5 } & Indicator & $\mathbf{2 0 1 7}$ & $\mathbf{2 0 1 8}$ & $\mathbf{2 0 1 7}$ & $\mathbf{2 0 1 8}$ \\
\hline $\begin{array}{c}\text { Increase Investment Realization } \\
\text { and Professionalism in } \\
\text { Licensing Services }\end{array}$ & Permission Request & 1043 & 1022 & 1017 & 998 \\
\cline { 2 - 5 } & IKM & $78 \%$ & $80 \%$ & $72 \%$ & $74 \%$ \\
\hline
\end{tabular}

Source: DPMPTSP Kabupaten Klungkung, 2018

Seen from table 1.1 the Targets and Realization of the Licensing Performance Indicator shows that there has been a decrease in terms of realization. This is because there are problems in the form of services that is not optimal from the implementation of one-stop integrated service in which the Department of Investment and One-Stop Integrated Services in licencing is not in one place. The technical team is still at its parent agency, for example to get the health permit, people must go to the Health Department to get recommendation. Research permit is also the same and to get all licenses for obtaining technical recommendation, people must go to the relevant department. Therefore, it takes time that make it not effective and efficient.

Viewed from this background, in which the principle of Presidential Regulation Number 97 of 2014 is to shorten the service process, coordination and delegation of authority in the Department of Investment and One-Stop Integrated Services in the implementation of one-stop integrated service has not run optimally. Therefore, in implementing the policy, it is very necessary to know, how the bureaucratic pathway, delegation of authority, and commitment of local government so that licensing services can run optimally. 


\section{Method}

The research approach used in this study is a qualitative descriptive approach. This research was conducted at the Department of Investment and One-Stop Integrated Services (Dinas Penanaman Modal dan Pelayanan Terpadu Satu Pintu) in Klungkung Regency, located on RA. Kartini street No. 33 Semarapura, Klungkung Regency. This place was chosen because there were problems in organizing one-stop integrated services so it needs an evaluation.

In accordance with the qualitative descriptive approach used, the instrument used to collect data is the researcher himself. Human instrument is a research instrument that is not external, but internal, namely the researcher himself as an instrument. In this case, researchers conducted planning, implementation, data collection, analysis, and interpretation.

\section{Result and Discussion}

Implementation of the One-Stop Service Policy at the Departmen of Investment and Integrated Services in Klungkung Regency

The most important task of each government office is to provide the services, because basically the establishment of the government agencies is intended as the main tool in providing the services to the public (Wijaya, 2018, 1). The implementation of the one-stop integrated services policy at the Department of Investment and One-Stop Integrated Services in Klungkung Regency in which the service patterns are held in one place covering various types of services that have a process linkage and are served through one door, get delegation from institutions that have licensing and non-licensing authority . The implementation of the one-stop integrated services policy set in Presidential Regulation No. 97 of 2014 concerning the implementation of one-stop integrated services. This department has implemented the one-stop integrated services policy.

The implementation of the one-stop integrated services policy in Klungkung regency is determined by the degree of implementability of the policy that is in the form of interests influenced by the policy itself. The implementation of the one-stop integrated services policy at the Department of Investment and Integrated Services in Klungkung Regency also experienced obstacles related to service standards that were not in accordance with the 
needs and expectations of the community. Bureaucracy often becomes an obstacle in implementing policies. The character of a bureaucratic organization that is supported by standard operational procedures allow it to be applied by the implementing team in equalizing the perception of similarity of actions in the organization.

The Department of Investment and One-Stop Integrated Service in Klungkung Regency received the delegation of authority in terms of licensing. Based on the Decree of the Regent of Klungkung Number 338/16 / HK / 2017 on amendment Number 46/16 / HK / 2017 concerning Delegation of Authority to Sign Licensing on Behalf of Bupati to the Head of the Department of Investment and Integrated Service in Klungkung Regency. The following are the types of licensing handled by this department and are still in the process of delegation.

The implementation of the one-stop integrated services policy in providing services to community users does not have a clear paradigm in terms of public services and maintaining a feudal bureaucracy. The transformation of the paradigm of the redesign of the system and organization of public services must be carried out so that the government is capable of carrying out obligations in providing services to the public. The people who use licensing services want one-stop integrated services to cut the bureaucratic chain in the management of permits; therefor, the service users in taking care of permits just need to go to One-Stop Integrated Services. The regional government of Klungkung regency has implemented one-stop integrated services policy in order to increase investment by forming the Department of Investment and One-Stop Integrated Services. The implementation of the Regional Investment Licensing Services in the Klungkung Regency, in this case has the main task of assisting the Regent in organizing the government in the area of promoting and licensing regional investment. The management of one-stop integrated services is part of public services that aim to provide services to the community, especially among the business world, in providing licensing and non-licensing services.

Licensing and non-licensing procedures are procedures, formal requirements and work processes that must be fulfilled by the One-Stop Integrated Services in the context of determining licensing and non-licensing decisions. One-Stop Integrated Services in the implementation of a permit and non-licensing activity that gets delegation of authority from an institution or agency that has licensing and non-licensing authority whose management 
process starts from the application stage to the issuance stage of documents carried out in one place. Improved licensing services are part of the government's efforts to provide better services to the community, including businesses, regional heads to accelerate the delegation of authority over the process of issuing permits and non-permits relating to business in the regions to the One-Stop Integrated Services to encourage them perform well. Business licensing is one of the things that must be passed by business actors who will start a business or are in the business development stage.

If the local government is seen from the perspective of the effectiveness of investment licensing services carried out by the One-Stop Integrated Services, some concrete evidences of investment licensing services have been described in the increase in investment licensing which has an impact on economic growth, licensing and non-licensing services, through one door service system. Furthermore, it is mentioned that what is meant by simplifying services is an effort to reduce the time, procedure, and cost of licensing and non-licensing. Besides, it is regulated about the duties of the agency having the task of carrying out coordination and organizing administrative services in the field of licensing in an integrated manner with the principles of coordination, integration, synchronization, simplification, security and certainty.

The implementation of Presidential Regulation Number 97 Year 2014 regarding the Implementation of One-Stop Integrated Services will be analyzed by using the Van Horn and Van Meter Theory. In detail, the variables of the implementation of public policy models, Van Meter and Van Horn states "there are 6 variables that affect implementation performance". The six variables are policy standards and targets, resources, communication between organizations and inauguration of activities, characteristics of implementing bureaucracy, level of compliance and responsiveness of target groups (social, economic and political conditions), disposition or attitude of implementers.

This theory explains that policy performance is influenced by several interrelated variables, these variables are the standards and objectives of the policy or size and policy objectives, resources, communication between related organizations and implementation activities, characteristics of implementing organizations, social environment, economy and politics, and attitude of the implementers. The following is the discussion of this research using the theory of Van Horn and Van Meter 


\section{Policy Standards and Targets}

Standards and targets must be formulated specifically and concretely so that it can be measured the extent of what has been implemented and how well the level of success is because policy performance is basically an assessment of the achievement level of these standards and targets have been implemented and how well the level of success. The implementation of good public services basically requires the involvement of all components of the stakeholders, both within the bureaucracy and in the community. The implementation of good governance is a government that is close to the community and in providing services must be in accordance with the needs of the community. One of the inherent views of most people is due to the lack of professionalism of officers in service organizations. This fact demands special attention for employees, especially those who work directly in the provision of public services. The implementation of the policy at the Department of Investment and One-Stop Integrated Services in Klungkung Regency is to get full delegation in licensing and non-licensing services that are still in the relevant Regional Apparatus Work Unit. Currently, 63 licencing are delegated in the authority from 31 licencing. In this case, the commitment form the leader to delegate authority about licensing services is very needed.

Viewed from the discussion, it is concluded that for the standard variables and policy objectives at the Department of One-Stop Investment and Integrated Services in Klungkung Regency are guided by Presidential Regulation 97 of 2014 concerning the Implementation of One-Stop Integrated Services. The standard operational procedures are used for reference in the licensing process in terms of time, cost and flow. The Regional Government of Klungkung Regency has implemented a One-Stop Integrated Services policy in order to increase investment by forming the Department of Investment and Integrated Services. For this reason, it can be seen that the policy standards and objectives are operating properly.

\section{Resource}

Policies require resources in the form of funds and other incentives that are likely to encourage the implementation of effective implementation.

Based on that explanation, it can be concluded that resource variable in the Department of Investment and One Stop Integrated Service Klungkung Regency in general has been able to carry out operational activities in the context of service effectiveness. 
Increasing the ability of human resources in the organizational environment is done by planning in accordance with the ability of the existing budget. Training and education related to the field of work are carried out, although there are obstacles in the structure due to existing budget constraints.

\section{Communication between Organizations and Inauguration Of Activities}

A policy, in order to be successful in its implementation, must create a good communication between the implementing organization and the determination and clarity in the implementation of the policy. Variable of communication between organizations and inauguration of activities at the Department of Investment and One-Stop Integrated Services of Klungkung Regency are well studied because the relationship between the implementing organizations and technical organizations must continue to coordinate in the completion of licensing recommendations in order to complete the licensing process. If it does not go well, then the procedure for administering licensing services is not fulfilled on time. It will be very detrimental to the community in licensing management.

\section{Characteristics of Implementing Bureaucracy}

Characteristics that can be mentioned include competency, range and degree of control, political support, organizational strength, degree of openness and freedom of communication and openness in relation to policy making. The variable of characteristics in implementing bureaucracy in the Department of Investment and One Stop Integrated Services of Klungkung Regency run quite well in which the organizational structure can be used as a variable that explains the characteristics of the organization. With the organizational structure, it will be clear for people who include factors such as the number of occupational specializations, scope of interpersonal formulation as well as arrangements for the use of technology to achieve goals and be efficient and effective and place employees in the organization based on their specialization.

The use of information technology is needed in public services. The Electronic Government Program aims to realize excellent service through increasing the scope of licensing services by the bureaucracy of regulation / city government in Indonesia. (Yusriadi, Y., Sahid, A., Amrullah, I., Azis, A., \& Rachman, A. A., 2018). In this technological era, it is time for the government to implement development using information technology to 
accelerate the development process. (Putra, D. A., Jasmi, K. A., Basiron, B., Huda, M., Maseleno, A., Shankar, K., \& Aminudin, N., 2018, 2251).

5. Level of Compliance and Target Group Responsiveness

This matter is based on several questions, for example with the economic resources that are owned to support the successful implementation and socio-economic conditions of the people affected by the policy. Licensing bureaucracy has not run efficiently and effectively, so that there are still many problems encountered in the service. Therefore, licensing service mechanism and management are absolutely necessary to create services that are fast, cheap, easy, transparent, certain, and affordable, so that they can attract the interests of business actors and investors.

Licensing service mechanism needed in supporting the implementation of One-Stop Integrated Service in the form of the needs of procedures and public service delivery systems that are carried out by them. From the aspect of service recipients, standard operating procedures that represent each type of licensing and non-licensing services become very necessary because they reflect the work mechanism of the One-Stop Integrated Service in processing every service they have. Transparency needed in the mechanism of the One-Stop Integrated Services' work is very crucial, so that all work mechanisms must be published openly and continuously, both through print and electronic media..

6. Disposition or Attitudes of Implementers

The attitude of individual implementers greatly influences the shape of their responses to the interrelationships between these variables. The form of implementing response becomes the cause of its success and failur. Implementing public services, hereinafter referred to as official actors, employees, officers, and everyone who works in the organizing organization at the Klungkung Regency One-Stop Investment and Services to carry out actions or a series of public service actions. As an actor in the implementation of the One-Stop Integrated Service policy is the administration of the government. In the process, it is not only carried out by the One-Stop Integrated Services but involves the technical service, prioritizing processes and procedures, in which in the process of preparation, planning, and formulation of a policy always prioritizing togetherness and carried out by involving all stakeholders. 


\section{Inhibiting Factors in Organizing One-Stop Integrated Services at the Department of One-}

\section{Stop Investment and Integrated Services in Klungkung Regency}

Administrative services are public services by the organizers that produce various forms of official documents needed by the public. One-stop integrated service delivery is only entitled to carry out administrative actions, namely the provision of documents in the form of licensing and non-licensing, while for guidance and supervision it remains the authority of the relevant agency or service needed by the community. Determination of the approval or rejection of the permit application is the authority of the relevant department through the assignment of a technical team in the unit of one-stop integrated licensing service.

As the administration of licensing services at the Office of Investment and One Stop Integrated Service of Klungkung Regency, it integrates the entire management process from the application stage to the issuance of licensing documents carried out in one place. On this basis, people who need licensing documents only need to take care of their licenses at the Klungkung Regency Department of Investment and One-Stop Integrated Services. They no longer need to go to the offices related to the permits they need.

b. Communication between organizations and their Target Groups Communication between related organizations and implementation activities is seen in terms of information on the pattern of its implementation, public services have various obstacles, among others:

1. Less responsive in which this condition occurs at almost all levels of service elements, starting at the level of service personnel (Front Liner) to the level of responsibility in charge. The response to various complaints, aspirations, and expectations of the community is often slow or even ignored altogether.

2. Less informative in which information that should be conveyed to the public is slow or not even reaching the community.

3. Less accessible in which various service delivery units are located far from the reach of the community, making it difficult for those who need these services.

4. Lack of coordination in which various service units related to one another are lacking in coordination. As a result, overlapping or conflicting policies often occur between one service agency and other related service agencies. 
5. Bureaucracy in which services, especially licensing services, are generally carried out through a process that consists of sharing levels resulting in the completion of services, very small possibility of service staff to be able to solve problems and on the other hand the possibility of the community to meet with the person responsible for services in order to solve problems that occur when the services provided are also very difficult. As a result, various service problems require a long time to be solved.

6. Less willing with complaints / suggestions / aspirations of the community where in general the service apparatus lacks the willingness to hear complaints / suggestions / aspirations from the community. As a result, the service is done as is without any improvement from time to time.

7. Inefficiencies where the various requirements needed for licensing applications are often not relevant to the services provided.

In terms of human resources, the inhibiting factors are related to professionalism, competence, empathy, and ethics. Various views also agree that one of the elements that needs to be considered is the problem of an appropriate compensation system, seen from the institutional side, lies in the organizational design specifically designed for the delivery of services to the community that is full of hierarchies which makes services complicated and uncoordinated. The tendency to perform two functions at the same time, namely the regulatory and administrative functions, causes public services become inefficient.

c. Resource

The One-Stop Integrated Service delivery policy at the Klungkung Regency Investment and Integrated One-Stop Service Department is inseparable from the social, economic and political environment. The quality of public services that are often complained by the public can occur due to various things. One internal determinant is the weakness of the government management control system. As is known at public service hours, the apparatus is often negligent in serving the community. The next problem is the lightness of the consequences of this negligence which has the potential to create a certain mental set of work responsibilities in each apparatus. This mental set becomes a derivation of work culture as it is common to be late, minimal quality of service, to complicate the process. In addition, other internal one is the placement of positions built horizontally between government officials and the community. 


\section{d. Organizational Characteristics and Implementing Attitudes}

The organizational structure of the Klungkung Regency Investment and Integrated One-Stop Services Department is a formal arrangement and mechanism with the name of the organization managed as a manifestation of the relationships between components of the position indicating the level of specialization of work activities. In this case, the division of labor is often not in accordance with the main job duties because the superiors prefer to disseminate the work to people considered able and easily invited to cooperate. This often happens and makes a jealous attitude towards careers that impact on poor service.

One-Stop Integrated Service bureaucratic structure that clearly regulates, all the required tasks and functions and the authority of each relevant work unit and personnel, and regulates the separation of functions and authorities in accordance with the main tasks and functions that have been determined as the basis for carrying out the task. Standard operating procedures for licensing and non-licensing services in the Department of Investment and Integrated Services Kungkung Regency is as a tool to carry out daily tasks but the application is still not good. It must be followed up One-Stop Integrated Service to socialize standard operating procedures to the entire scope of government units areas related to licensing and non-licensing.

1. The nature of standard operational procedures to avoid miscommunication, conflict, and problems in carrying out the task or job.

2. Standard operational procedures are written instructions that describe precisely how to carry out the task or work. The mechanism communicates the regulations and administrative requirements, organizational policies and strategic planning for implementers.

Permit documents issued by the Klungkung Regency based on regional regulations or other regulations that constitute proof of legality, state that a person or entity is authorized or permitted to conduct certain businesses or activities. Service problems often occur due to weak coordination between One-Soor Integrated Services with technical agencies. Egosectoral still occurs when coordination prior to issuance of permits, eventually impacting the service takes a long time not in accordance with standard operating procedures that have been determined. 
Supporting implementers, technical agencies, local governments, communities and leadership commitment.

The implementation of the policy is supported by implementers, technical technical agencies, local governments, the community and the leadership's commitment.

1) The tendency of attitude supports the implementation of the One-Stop Integrated Services policy by the Klungkung Regency Investment and Integrated One Stop Services Office and all implementers, agencies in the local government and the community is as one of the objectives of the organization in implementing the OneStop Integrated Services policy.

2) The tendency of attitudes by the Regent in the implementation of the One Stop Integrated Services policy requires a strong commitment from the regional leadership namely the Regent in terms of delegating authority for licensing services which are still scattered in several technical agencies.

3) The tendency of the implementor's attitude is as one of the keys to its success in the implementation of the One-Stop Integrated Services policy, because the implementor is the vanguard in providing licensing services to the public, from entering registration until the issuance of a permit lies with the implementor.

4) The attitude of several elements related to licensing services is a unity in achieving the goal of implementing a one-door service policy. It is how to equate perceptions of vision and mission of licensing service organizations.

The attitude of some elements related to the One-Stop Integrated Service provides a licensing and non-licensing that has the support and commitment to delegate authority. The implementation of policies is fully supported by the Regional Government, to provide services that are transparent, equal, easy, efficient, fast, fair, accountable, and legal certainty, required services in the investment sector, both licensing and non-licensing services carried out in an integrated manner which is called the One-Stop Integrated Service in the Field of Investment, as mandated in Act Number 25 of 2007 concerning Investment, Presidential Regulation Number 97 of 2014 concerning One-Stop Integrated Services.

Implementation of policies is hampered in communication by implementers, technical agencies, local governments, communities and the commitment of leaders. 
1) In communication, the implementation of policies to run the licensing service organization in a clean bureaucracy in providing services to the public has not been supported by good communication.

2) As for communication, there are obstacles in the service that must be repaired, licensing has not run effectively and efficiently. Permits are proven, there are still licensing services that are still in the technical authority, the authority has not been delegated.

3) Ineffective coordination in which the conflicts of interest often occur. Therefore, that service users are disadvantaged.

4) Coordination with the technical team often results in obstacles in the field so that this often occurs a conflict of interest, which results in services that are not in accordance with standard operating procedures.

5) Communication between One-Stop Integrated Services and technical teams in other agencies is less effective.

For the inhibiting factors, in particular the communication with the technical team and the lack of completeness of the requirements that must be found by the public, this means that there is a community that manages the service. Based on the writer's observation, in coordination with the technical team there are obstacles so that the service recipient feels less satisfied, this is a finding for the writer as one of the inhibiting factors in the service, because basically time is one of the benchmarks of the success of a service.

The implementation of policies is hampered in the competence of human resources by implementers, technical agencies, local governments, and the community.

1) The placement of human resources is not in accordance with the educational background so that the service is not optimal. To improve human resource competence, education and training are needed. With limited human resources, there is a need to recruit new employees so that service can be maximized.

2) The implementation of the One-Stop Integrated Services in the investment sector is motivated by the investment climate through the improvement of licensing service mechanisms that are still inadequate, as well as the problem of lack of quality in human resources. 
3) The implementation of policies on the type of licensing services, to encourage investment realization, but it is recognized that there are problems with less skilled human resources.

4) The development of human resources in the Department of Investment and One-Stop Integrated Services in Klungkung Regency to evaluate the conditions of licensing services. It can prepare competent human resources to run the One-Stop Integrated Services program so that it can be improved even better.

The competence of human resources involved in the implementation of the One-Stop Integrated Service is also very dependent on the concept and strategy of manpower planning that is implemented by the regional apparatus that handles the field of staffing, education and training. The policy issued by the regional apparatus in the field of staffing and education and training will greatly influence the formation of character, motivation, achievement and competence of regional human resources placed into the One-Stop Integrated Service organizational environment. Therefore, the determination and stipulation of formal education prerequisites, non-formal education, work experience and the application of staff development strategies that are in accordance with the competency needs of the One-Stop Integrated Service will significantly influence the performance of the One-Stop Integrated Services significantly.

The physical facility is an information technology problem wherein the information system is licensing and non-licensing services to provide information and an overview of service levels. The implementation of the policy on information technology issues has not yet been supported by implementers, technical agencies, local governments, and the community. At present, the supporting facilities already exist, but it is necessary to increase the volume and type of existing facilities as a support in carrying out the duties and functions of the OneStop Investment and Integrated Services Office in the future.

Licensing Services in the framework of implementing the One-Stop Integrated Services policy at the Klungkung Regency Investment and One-Stop Integrated Services Department are managing licensing and non-licensing administration with reference to the principles of coordination, integration, synchronization, and file security. Integrated services have all the authority needed to provide licensing services (licenses, permits, approvals and clearances). 
Without an authority capable of handling all of these matters, government agencies cannot regulate during the process.

\section{Solution to optimize the implementation of one-stop integrated services in the Department of Investment and One-Stop Integrated Services in Klungkung Regency}

From the results of the research, it can be seen that the solution for implementing a one-stop integrated service policy in the investment service and one-stop integrated service in Klungkung regency is that good public services will be realized if there is a service system in the service organization that prioritizes the interests of the community, especially service users and oriented human resources in the interests of the community. The implementation of good public services, provides an indication of the improved performance of government management, on the other hand shows a change in mindset that affects better changes in the mental attitude and behavior of government officials oriented to public services.

The principle of accountability, transparency, and participation in good governance can also be interpreted as the accountability of the government to the community in accordance with the paradigm of democracy in which the public has the right to participate in developing service standards according to the field of ability in terms of related services. This principle is the most important thing supported by transparent and applicable public laws and policies so that it reflects the alignments according to the rights and obligations of the service providers and recipients. The following are the evaluation results of the implementation of the One-Stop Integrated Services policy for the future:

1. Creation of deregulation and debilitating encourages the implementation of policies to be relevant and animate public service policies

2. The implementation of an integrated service system through the Public Service Mall is very dominant in fulfilling licensing services to the one-stop integrated community

3. Decentralization in the transfer of service authority to deal with licensing and nonlicensing within the framework of improving services to the community

In accordance with the results of the study as described above, it is recommended that the Regional Government of Klungkung Regency continue the implementation of the OneStop Integrated Services policy set out in Presidential Regulation No. 97 of 2014 concerning the Implementation of One Stop Integrated Services and Law Number 25 of 2009 concerning 
Public Services. In connection with this, it is to increase licensing services and investment for the community.

The Klungkung Regency Government in implementing the policy is recommended to take steps to improve its implementation as follows:

1) Policy Communications.

a) The Government of Klungkung Regency should prepare a technical policy in the form of a regional regulation for the implementation of the policy by referring to Presidential Regulation No. 97 of 2014 concerning the Implementation of One-Stop Integrated Services.

b) The Government of Klungkung Regency has to continuously carry out evaluations of policy implementation and make breakthroughs in formulating policies that are simple, easy, and clear so that it is easy to implement.

c) Head of One-Stop Integrated Service takes strategic steps in coordination with technical agencies, to communicate policies before permission is issued to get recommendations from the technical team.

2). Resource

Local Governments should take strategic steps to improve the competence of human resources and physical facilities in the field of licensing services:

(a) The Head of the One-Stop Integrated Services conducts education and training programming for employees in the One-Stop Integrated Services in the field of services, in order to improve the competence of human resources to be able to support the implementation of the One-Stop Integrated Services policy.

(b) Communicating the One-Stop Integrated Services policy to all implementers / employees and making new breakthroughs in increasing licensing and non-licensing services to overcome the shortcomings and weaknesses of policy communication from the Central Government so as to enable policy implementation to run properly.

(c) Conducting socialization to all implementers of the policy issue of Presidential Regulation number 97 of 2014 concerning Implementation of One-Stop Integrated Service.

(d) Conduct consultations with academics and practitioners who are competent in service issues, in the formulation of licensing and non-licensing service policies. 
(e) Recruit employees or take employees from other agencies, which are appropriate with their educational background and have the ability in the field of services and mastering information technology.

(f) Local governments to provide the necessary supporting facilities and infrastructure such as computer equipment, servers in the form of integrated licensing service information systems.

3) Trends in the Attitudes of Internal and External Parties.

a) The Regional Government and the Head of the Klungkung Regency Office must maintain a shared commitment to support the implementation of the One-Stop Integrated Services policy and encourage a positive attitude from the implementing staff to change routine activities in providing services to the community as to be guided by operational standard procedures in licensing services.

b) Head of Integrated One-Stop Service improves coordination with regional work units in the process of giving permits to service users.

c) Local governments maintain and enhance service support to the community, thereby encouraging the commitment of all parties involved in implementing the One Stop Integrated Services policy.

d) Local governments commit to support policy implementation in order to increase investment.

4) Bureaucratic Structure

a) Local Governments should follow up on the implementation of policies by evaluating the delegation of authority and coordination between the One-Stop Integrated Services with technical agencies.

b) The Head of the One-Stop Integrated Service evaluates policies and operational standards for licensing service procedures, is it still relevant or needs to be revised again. Therefore, it is in accordance with the One-Stop Integrated Services policy and the implementers should be encouraged to support changes in old habits in conducting licensing services that are no longer appropriate with a One-Stop Integrated Services policy.

c) Local Governments and Head of Integrated One-Stop Services make service promises as a form of commitment in providing services to the public service users. 
The implementation of good public services, provides an indication of the improved performance of government management, on the other hand shows a change in mindset that affects better changes in the mental attitude and behavior of government officials oriented to public services. The principle of accountability, transparency, and participation in good governance can also be interpreted as the accountability of the government to the community in accordance with the paradigm of democracy in which the public has the right to participate in developing service standards according to the field of ability in terms of related services. This principle is the most important thing, supported by transparent and applicable public laws and policies so that it reflects partiality in accordance with the rights and obligations of providers and recipients of services.

The solution for optimizing the implementation of the One-Stop Integrated Service Policy at the Investment Office and the One-Stop Integrated Services in Klungkung Regency is as follows:

1) It is necessary to strengthen the delegation of authority, the commitment of the leadership, this is to build a professional bureaucracy, currently the bureaucracy seems convoluted, long so that slow licenses are issued because of coordination communication problems between the One Stop Integrated Service with technical agencies that still have obstacles.

2) Hoping that all permits can be administered immediately in one office and will no longer be distributed in each agency. Thus, investor interest in investing is increasingly high.

3) There needs to be a strong commitment to strengthening the delegation of licensing authority to improve services to the community, in order to attract investment in Klungkung Regency for various developments.

4) Implementation of policies in their organizations needs to strengthen the delegation of authority of the One Stop Integrated Service.

Good public services will be realized if there is a service system in the service organization that prioritizes the interests of the community, especially service users and human resources oriented to the interests of the community. The implementation of good public services, provides an indication of the improved performance of government management, on the other hand shows a change in mindset that affects better changes in the 
mental attitude and behavior of government officials oriented to public services. The principle of accountability, transparency, and participation in good governance can also be interpreted as the accountability of the government to the community in accordance with the paradigm of democracy in which the public has the right to participate in developing service standards according to the field of ability in terms of related services. This principle is the most important thing, supported by transparent and applicable public laws and policies so that it reflects partiality according to the rights and obligations of providers and recipients of services.

The creation of deregulation and debiroktisasi encourages the implementation of policies to be relevant and animates public service policies in the era of regional autonomy. It is aimed at improving the performance of central and regional government management, changing mental attitudes, behavior of service providers and building awareness and commitment of regional leaders and their apparatus to improve and improve quality public services.

\section{Conclusion}

\section{Summary}

The implementation of the one-stop integrated service delivery policy at the Klungkung Regency Investment and One-Stop Integrated Services Department in the implementation of the One-Stop Integrated Service policy shows a tendency for increasingly improving attitudes. In which the results of the discussion showed that the Standards and policy objectives are guided by PP 97 of 2014 concerning the implementation of One-Stop Integrated Services. Resources in general have been able to carry out operational activities in the context of service effectiveness. Communication between organizations and inauguration of activities went well. The characteristics of the implementing bureaucracy run quite well in which the Organizational Structure can be used as a variable that explains the characteristics of the organization. Licensing bureaucracy has not run efficiently and effectively, so that there are still many problems encountered in the service. Therefore, licensing service mechanism and management are absolutely necessary to create services that are fast, cheap, easy, transparent, certain, and affordable, so that they can attract the interests of business actors and investors. 
Implementing public services in the process is not only carried out by the One-Stop Integrated Service but involves technical offices, prioritizing processes and procedures. Factors hampering the implementation of the one-stop integrated service delivery policy at the Klungkung Regency Investment and One-Stop Integrated Service Office include differences in perceptions regarding the contents of the one-stop integrated service delivery policy, human resource factors, minimum service quality, and potential distribution in bureaucratic structure in which the Standard Operating Procedures in the implementation of services are not in accordance with the Standard Operating Procedures regarding time. Thus, it needs to be socialized to the implementers and all service users.

\section{Suggestion}

The implementation of the One-Stop Integrated Service Policy in the Regions will be effective to be implemented if applying the implementation model with the transfer of authority to the One-Stop Integrated Service, henceforth the policy is a complete, clear, measurable and consistent instructions to be controlled in its implementation. The implementation of the policy in Klungkung Regency is inseparable from the monitoring and evaluation aspects in order to produce, support, information, implementing compliance with the policy and followed by completion, in order to improve the implementation of the policy being an important aspect in the implementation of the One-Stop Integrated Service policy in Klungkung Regency.

\section{References}

Putra, D. A., Jasmi, K. A., Basiron, B., Huda, M., Maseleno, A., Shankar, K., \& Aminudin, N. (2018). Tactical steps for e-government development. International Journal of pure and applied mathematics, 119(15), 2251-2258.

Sinambela, L.P. (2006). Reformasi Pelayanan Publik:Teori, Kebijakan, dan Implementasi.. Bumi Aksara.

Umar, A., Madani, M., Farida, U., Yusriadi, Y., Tamsa, H., Yahya, M., ... \& Sakkir, G. (2019). One-Stop Service Policy as a Bureaucratic Reform in Indonesia. Academy of Strategic Management Journal, 18(2), 1-12. 
Wijaya, A. S. (2018). The Public Service Ethics in Bali in The Bureaucratic Reform Era. Journal of Public Administration and Local Governance, 2(2), 1-5.

Yang, Y. (2016). The Optimal Routing of Public Service by Local Government-- A New Public Administration Angle. Journal of Southwest Petroleum University (Social Sciences Edition), (5), 6.

Yusriadi, Y., Sahid, A., Amrullah, I., Azis, A., \& Rachman, A. A. (2018, July). E-Governmentbased Bureaucratic Reform in Public Service. In International Conference of Communication Science Research (ICCSR 2018). Atlantis Press. 